\title{
ФРАЗЕОЛОГИЗМЫ, РЕПРЕЗЕНТИРУЮЩИЕ ВЫСОКОМЕРИЕ ЧЕЛОВЕКА, В КУМЫКСКОМ ЯЗЫКЕ
}

\section{PHRASEOLOGISMS REPRESENTATIVE OF ARROGANCE IN THE KUMYK LANGUAGE \\ N. Hajiakhmedov \\ G. Temirkhanova}

Summary: The article considers the functional-semantic nature of phraseological units that objectify human arrogance in the modern Kumyk language. The study revealed a rich body of phraseological units that characterize an arrogant person in the Kumyk language. These phraseologisms have a special semantic load, with the help of which the image is created, individual features of arrogance manifested in relation to oneself are emphasized. Comprehension of arrogance has a gradual character: from minimal to maximum assessment. Moreover, the higher the gradation, the brighter the image created by the mentality of native speakers. All positions of arrogance are condemned by other people. In creating the image of an arrogant person, zoomorphic, somatic, spatial culture codes are used.

Keywords: arrogance, arrogance, conceit, phraseological unit, Kumyk language.
Гаджиахмедов Нурмагомед Эльдерханович nрофессор, Дагестанский государственный университет (г. Махачкала), nur1@yandex.ru

Темирханова Гульнара Каирхановна преподаватель, Дагестанский государственный университет народного хозяйства (г. Махачкала), sapukova92@mail.ru

Аннотация: В статье рассматривается функционально-семантическая природа фразеологических единиц, объективирующих высокомерие человека, в современном кумыкском языке. В результате исследования выявлен богатый корпус фразеологических единиц, характеризующих высокомерного человека в кумыкском языке. Эти фразеологизмы имеют особую смысловую нагрузку, с помощью которой создается образ, подчеркиваются индивидуальные черты высокомерия, проявляющиеся в отношении к самому себе. Осмысление высокомерия имеет градуальный характер: от минимальной до максимальной оценки. Причем, чем выше градация, тем ярче образ, созданный менталитетом носителей языка. Все позиции высокомерия вызывают осуждение со стороны других людей. В создании образа высокомерного человека использованы зооморфный, соматический, пространственный коды культуры.

Ключевые слова: высокомерие, надменность, зазнайства, фразеологизм, кумыкский язык.

фразеологизмов кумыкского языка [Даибова 1973, 1981], Гаджиахмедов 2013] и художественные произведения современных кумыкских авторов.

ческими единицами представляет собой один фрагментов образной характеристики человека в языковой картине мира. В языковом сознании это чувство особенно ярко выражается в ФЕ, имеющих культурно-ситуативную обусловленность и характеризующихся определенной этнокультурной спецификой.

Актуальность темы определяется не только отсутствием специальных исследований, посвященных изучению ФЕ семантического поля «черты характера человека, проявляющиеся в отношении к самому себе», но и в выявлении устойчивых выражений, отображающих образность данных единиц во фразеологической картине мира кумыков. Кроме того, одной из актуальных проблем кумыкской фразеологии является изучение функционально-семантической природы фразеологизмов в произведения современных кумыкских авторов [Даутова, Гаджиахмедов 2014].

Целью данной статьи является выявление образного потенциала ФЕ, репрезентирующих высокомерие человека в языковом сознании кумыков.

Материалом для исследования послужили словари
Кумыкский язык обладает богатым потенциалом ФЕ, репрезентирующих характер человека. Эти фразеологизмы имеют особую смысловую нагрузку, с помощью которой создается образ, подчеркиваются индивидуальные черты характера человека. Объектом исследования являются ФЕ, характеризующие человека по отношению к себе.

Высокомерие относится к черте характера человека, которая проявляется в отношении к самому себе. Это качество человека представлено в кумыкской фразеологической картине мира представительным корпусом ФЕ.

Чаще всего для репрезентации высокомерия используются фразеологизмы с соматическими компонентомами баш «голова» и бурну «нос»: бурнун чюймек (букв. нос [свой] поднять) «задирать нос, держаться надменно, важничать, зазнаваться», бурнун гётермек (букв. нос [свой] поднимать) «задрать нос, зазнаться, заважничать», керки баш (букв. кирка голова) «о важном, высокомерном человеке». Бурнун чюйген сюрюнмей къалмас. (Погов.). 
«Задравший нос споткнется». «Алып бар муну, ерине сал», - деди Анайгъа, бурнун чююрюn (Абзайдин Гьамитов). «Унеси это, поставь на свое место», - важно сказала она Анай».

Осмысление высокомерия, как и гордости, имеет градуальный характер [Карасик 2018: 157]. Самая высокая степень высокомерия - надменное высокомерие и дерзновенность, осложненные оттенком пренебрежительного отношения к окружающим - выражается фразеологизмом ханына салам бермей (досл. он не приветствует даже своего хана) «надменный, очень гордый и высокомерный человек». Оьктемлигинден ол чу ханына да салам бермей (Ибрагьим Ибрагьимов). «От высокомерия он даже со своим ханом не здоровается». Агъачлыкъгъа гирсек чи, ханыбызгъа салам бермейген болажакъ эдик. (Ибрагьим Керимов). «Если бы мы зашли в лес, мы при встрече даже со своим ханом не поздоровались бы».

Для репрезентации мнимой гордости с выраженным высокомерием и безразличием к окружающим используется соматический фразеологизм мыйыгъын балта гесмей (досл. ус [его] топор не режет) «очень важный, высокомерный». Сёйлеп де англатма къарадым - мыйыгъын балта гесмей. (Ибрагьим Керимов). «Я попытался с ним поговорить, объяснить - ему безразлично».

В ФЕ, объективирующих высокомерие, используются глаголы-интенсификаторы, которые своим содержанием усиливают степень напряженности ФЕ. К таким глаголам относятся ярылмакъ «лопаться», шишмек «дуться»: оьктемлигинден ярылып бара тура «от высокомерия лопается», оьктемлигинден шиши гетме тура «от важности может вздуться». Например: Ол чу оьктемлигинден ярылып бара тура (Амир Къурбанов). «Он же от высокомерия вот-вот лопнет». Оьктемлигинден шишип гетме mура! (Микайыл Абуков). «От высокомерия он вздулся!»

Про человека, который не уважает окружающих его людей, ставит себя выше других в обществе, кумыки говорят: сан этмей (букв. сан «внимание» + этмей «не делает») «ни во что не ставит; не считается с кем; не обращает внимания». Тек о бек оьктем къыз, тилегенлени сан этмей (Алим Къабардиев). «Однако, она очень гордая девушка, сватов не признает».

Интересным смысловым содержанием обладают ФЕ с зооморфным кодом культуры, репрезентирующие высокомерие: оьктем хораз (досл. «гордый петух») «гордец, высокомерный», кёр бугъа (досл. слепой бык) «очень гордый, напыщенный человек, гордец» и др. Во фразеологизме оьктем хораз отражена особенность походки петуха, который ходит, высоко подняв свой хохол. Считается, что хораз «петух» объективирует гордость на основе именно этого признака. В результате метафориче- ского переноса на основе сходства внешних признаков петуха с человеком, данный фразеологизм стал выражать значение «гордый и высокомерный человек». Оьктем хораз йимик башын гётерип айлана (И. Керимов). «Ходит важный, как петух, высоко подняв голову». Майорну ягъына Семён Семёныч хораз йимик хохайып гирди. (Ибрагьим Керимов). «Семен Семенович очень важный подошел к майору.

Гендерно маркированный фразеологизм хохайгъан хораз йимик «важный, как петух» характеризует недовольного, задиристого мужчину, демонстрирующего внешне свой важный вид

Во фразеологизме кёр бугъа (досл. слепой бык) значение высокомерия приобретает еще большую степень проявления, и ФЕ репрезентирует очень гордого, очень высокомерного, напыщенного человека, на основе внешних признаков данного животного - это характерный внешний вид быка и нежелание даже смотреть на окружающих. Кёр бугъадай айланасан абзарда (И. Ибрагьимов). «Что ты ходишь, как слепой бык по двору».

С зоонимическим кодом культуры, а именно с зоонимом бугъа «бык», связаны значения еще двух глагольных фразеологизмов - это бугъа йимик ер къаза (досл. как бык землю роет) «чрезвычайно высокомерный», бугъа йимик оькюре (досл. как бык ревет) «чрезвычайно высокомерный». Эти фразеологизмы выражают высочайшую степень высокомерия, надменности человека. Если в предыдущих примерах высокомерие реализуется через характерный внешний вид и нежелание даже смотреть в сторону окружающих, то в рассматриваемых двух фразеологизмах человек, исполненный высокомерия, отличающийся высокомерием репрезентируется через издаваемые быком звуки и физические действия.

Таким образом, во ФЕ, где основанием для выражения гордого, высокомерного человека являются орнитоним хораз «петух» и зооним бугъа «бык» с характерными для петуха и быка качествами, отражающими специфику мировосприятия носителями кумыкского языка.

В рассмотренных выражениях, внутренняя форма которых указывает на разное положение хвоста, реализуется ориентационная метафора хорошее - это верх, плохое - это низ [Лакофф 2004: 40]. Образная основа отсылает к поведению собак, поднятый хвост которых говорит об их хорошем, радостном настроении, а опущенный хвост свидетельствует об обратном: собаки часто поджимают хвост, когда их ругают или наказывают. Однако фразеологизм къуйругъун гётермек «поднять хвост» имеет метафорическое значение, связанное с поведением собаки, у которой поднятие хвоста выражает значение «важный». Тюнегюн старшина Осман большевиклерден къоркъуп яшына эди, бугюн буса къуйругъун 
гётерun геле. (А. Къурбанов). «Вчера старшина Осман боясь большевиков, прятался, а сегодня идет, подняв хвост». Ол мырыллап турду, сонг къуйругъун къысып, гетип къалды (А. Мамаев). «Он что-то бормотал, потом прижав хвост, ушел».

Соматические фразеологические единицы башын гётермек «поднять голову» и къуйругъун гётермек «поднять хвост» репрезентируют не просто высокомерие, а демонстративно подчёркивающее своё более высокое положение в обществе. Образная основа связана с соматизмами баш «голова» и къуйрукъ «хвост», которые выражают пространственное значение «поднять вверх», демонстрирующее самолюбование, самоутверждение, высокомерие свою исключительность: Агьмат баш гётерген къатынына оьзюню хожайынлыкъ ихтиярларын гёрсетмек мурат булан атылып тургъан эди (Ю. Гереев). «Ахмед, желая показать поднявшей ему голову жене, кто в доме хозяин, резко встал».

Для репрезентации значения «высокомерие» в кумыкской фразеологической картине мира используется орнитоним гюргюр «индюк». По ассоциации с внешним видом этой «надутой птицы» возникли фразеологизмы гюргюрдей гёпмек (букв. как индюк дуться) «дуться, обижаться; о гордом, чванливом человеке», гюргюрдей хохаймакъ (букв. как индюк хорохориться) «дуться, обижаться; о гордом, напыщенном, чванливом человеке», гюргюрдей хахайыш «хорохоривание как индюк», гюргюрдей гёбюп юрюмек (досл. ходить надутым как индюк) «о гордом, напыщенном человеке». Хуйланып, гюргюрдей хахайыn, бир уьйден бир уьйге гезейсен. (У. Мантаева) «Обидевшись, надувшись как индюк, ходишь из одной комнаты в другую».

Орнитоним гюргюр «индюк» используется для описания высокомерного, надутого человека в фразеологизмах биревге гёпмек (досл. надуться на кого-л) «разозлиться, надуться на кого-л.», гёбюп турмакъ «дуться, злиться», ачувундан гёпмек «дуться от злости». Гьамзат агъав ачувундан гёбюп айлана (Микайыл Абуков). «Дядя Гамзат от злости ходит надутый». Аз эришивлюк учун де гёбюn турмасын. (Микайыл Абуков). «Пусть не надувается из-за небольшого спора».

В кумыкской языковой картине фразеологизм уллу юрек «большое сердце» является носителем негативной характеристики человека. ФЕ уллу юрекли (досл. с большим сердцем) «гордый, высокомерный», в котором атрибут выражен качественным прилагательным уллу «большой», дает человеку отрицательную характеристику. Шолай уллу юрекли гиши буссагьат къарарда бар кюйде, бизге ярыкъ да, сув да чыгъарсын (Аткъай Гьажамматов). «Такой высокомерный человек в соответствии с постановлением, сейчас же пусть проведет нам свет и воду».
Высокомерный человек любит говорить о себе. Самонадеянного человека, который слишком часто в речи произносит мен «я», характеризует фразеологизм менмен деп турагъан адам «любящий якать; высокомерный, надменный». В сердце и мыслях такого человека нет места ни для кого: собственное мен «я» занимает все пространство. Ол чу къуру «менмен» деn турагъан адам (Ибрагьим Керимов). «Он человек, который все время любит якать».

Гордый человек стремится быть заметным, совершая дела напоказ, тем самым он хочет добиться от других расположения, желает услышать похвалу в свой адрес

Именных фразеологизмов, репрезентирующих высокомерного, гордого человека в кумыкском языке немного: хохабаз адам // хохабаз гиши «гордец», «зазнайка», хохабаз хасиятлы «с гордым характером». Хохабаз хасиятлы улан юртну ичиндеги къызлар барысы да оьзюне гъашыкъ деп ойлагъан. (Зарипат Атаева). «Зазнайка-парень думал, что все девушки села влюблены в него».

Чрезмерная гордость, чрезмерно высокое мнение о себе, неразумная и всепоглощающая любовь к своей персоне - отрицательная черта характера. Такой человек в кумыкской фразеологической картине мира характеризуется соматическими фразеологизмами уллу юрек тутмакъ (досл. большое сердце держать), юрегин уллу тутмакъ (сердце большое держать) «быть гордым, высокомерным», оьзюн уллу тутмакъ «держать себя высокомерно, гордо». Например: Ол гьали юрегин уллу тутагъан болгъан (Амир Къурбанов). «Теперь он стал гордым и высокомерным». Все эти фразеологизмы имеют пространственную ориентацию, на что указывает прилагательное уллу «большой».

Пространственную ориентацию имеют и фразеологизмы оьзюн оьр тутмакъ (досл. себя верх держать) «держать себя высокомерно, гордо», оьзюн оьр салмакъ (досл. себя верх ставить) «ставить себя выше других», оьзюн оьр гёрмек (себя высоко видеть) «смотреть на всех свысока, вести себя высокомерно». Эгер халкъдан оьзюн оьр салca, ондан гьаким болмай (Ибрагьим Ибрагьимов). «Если себя ставит выше народа, из него руководитель не получится». Буса да юрегингни уллу тутасан, оьзюнгню оьзгелерден айры тутма (А. Къурбанов). «Все-таки ты держишь себя высокомерно, не держи себя выше других».

Таким образом, прилагательные уллу «большой» и оьр «высокий, выше», имея пространственную ориентацию, образуют соматические фразеологизмы с отрицательной характеристикой человека. Позиция высокомерного человека в пространстве характеризуется как «значительная по величине» или «положение наверху».

Надменный человек обычно ставит себя выше окру- 
жающих, демонстрирует собственное превосходство над остальными людьми. Об этом говорит фразеологизм башгъаланы пешемейген // оьзгелени пешемей (досл. других [людей] не признает», пешемей къарамакъ «смотреть свысока», пешемей сёйлемек «говорить с пренебрежением». Солтанмут ортанчы агъасына пешемей къарай. (Баммат Атаев). «Солтанмут смотрит на среднего брата свысока».

Однако в кумыкской фразеологической картине мира высокомерный человек - это не только тот, кто ведёт себя так, будто бы он выше других, но и тот, кто даже своего отца родного не признает: атасын танымай (досл. отца не узнает) «о возгордившемся человеке», атасын пешемей (досл. отца не признает) «очень высокомерный человек». Ол чу атасын да пешемей, чанчып сёйлей (Микайыл Абуков). «Он же родного отца не признает, подкалывает».
Таким образом, в современном кумыкском языке представлен специальный корпус фразеологизмов, предназначенных для характеристики высокомерного человека. Эти фразеологизмы имеют особую смысловую нагрузку для репрезентации высокомерного человека. Осмысление высокомерия имеет градуальный характер: от минимальной до максимальной оценки. Причем, чем выше градация, тем ярче образ, созданный менталитетом носителей языка. Все позиции высокомерия вызывают осуждение со стороны других людей. В создании образа высокомерного человека используются зоонимический, соматический и пространственный коды культуры. Внешне высокомерие отражается в высоко вздернутом носе, поднятой голове и походке. Позиция высокомерного человека в пространстве характеризуется как «значительная по величине» или как «положение наверху».

\section{ЛИТЕРАТУРА}

1. Гаджиахмедов Н.Э. Кумыкско-русский фразеологический словарь. Более 3300 фразеологизмов. - Махачкала: 2013. - 300 с.

2. Даибова К.Х. Кумыкско-русский и русско-кумыкский фразеологический словарь. Под ред. И. Керимова. — Махачкала: Дагучпедгиз, 1981. — 99 с

3. Даибова К.Х. Къумукъ тилни къысгъа фразеология сёзлюгю (Ана тил учителлери учун пособие). - Магьачкъала, 1973. —70 6.

4. Даутова Ф.И., Гаджиахмедов Н.Э. Кумыкская фразеология: современное состояние и перспективы развития // Современные проблемы науки и образования 2014. - № 3. URL:www.science-education.ru/l 16-12544

5. Карасик В.И. Осмысление гордости в русской и английской лингвокультурах // Вестник РУдН. Серия: Русский и иностранные языки и методика их преподавания. 2018. Вып. 16 №. 2. - С. 157-171.

6. Лакофф, Дж. Метафоры, которыми мы живем. - М.: Едиториал УРСС, 2004. -256 с.

( Гаджиахмедов Нурмагомед Эльдерханович (nur1@yandex.ru), Темирханова Гульнара Каирхановна (sapukova92@mail.ru). Журнал «Современная наука: актуальные проблемы теории и практики» 